\section{Sampling bias in Brazilian studies on transgender and gender diverse populations: the two-step measure for assessing gender identity in surveys}

\author{
Viés amostral em estudos brasileiros sobre \\ populações transgênero e não binárias: \\ a medida de dois passos para avaliar a \\ identidade de gênero
}

Angelo Brandelli Costa 1

Letícia de Oliveira Rosa 1

Anna Martha Vaitses Fontanari 2,3

\begin{abstract}
Correctly recognizing gender identity in population-based surveys is essential to develop effective public health strategies to improve the living conditions of transgender and gender-diverse populations, as well as to adequately collect data on cisgender individuals. This study aims to present the two-step measure as the best strategy for assessing gender identity in Brazilian surveys, thus we performed two separate analyses. Firstly, we conducted a systematic review concerning HIV-related care among Brazilian transgender and gender-diverse populations to assess the strategy used to identify participants gender identity. Secondly, we re-analyzed data from a recent survey that included Brazilian transgender populations, comparing characteristics and health outcomes from the sample identified by single-item and by the two-step measure. Concerning the systematic review, from 6,585 references, Brazilian research teams published seven articles, and only one study used the two-step measure. Regarding this survey, the two-step measure recognized 567 cisgender and 773 transgender and gender diverse participants among the 1,340 participants who answered the questionnaire, whereas the single-item measure was able to recognize only 540 transgender and gender diverse people. Furthermore, 31 transgender women self-identified as "transgender men" on the single-item measure. Therefore, although scarcely used in Brazil, the twostep measure is a more accurate strategy to recognize gender identity.
\end{abstract}

Gender Identify; Surveys and Questionnaires; Systematic Review; Selection Bias

\author{
Correspondence \\ A. B. Costa \\ Pontifícia Universidade Católica do Rio Grande do Sul. \\ Av. Ipiranga 6681, Porto Alegre, RS 90619-900, Brasil. \\ angelo.costa@pucrs.br \\ 1 Pontifícia Universidade Católica do Rio Grande do Sul, \\ Porto Alegre, Brasil. \\ 2 Universidade Federal do Rio Grande do Sul, Porto Alegre, \\ Brasil. \\ 3 Western Ontario University, Ontario, Canada.
}




\section{Introduction}

In the early 1990s, transgender appears as an umbrella term encompassing a wide spectrum of gender identity variations that share the incongruence between one's current gender identity and one's gender assigned at birth. Although a subgroup of transgender people may seek medical gender affirmation - such as hormonal therapy and surgical procedures - transgender is not a nosological classification 1,2. Gender identities as social categories vary significantly across cultures. In Brazil, for example, subgroups of transgender populations may self-identify as travestis and/or trans(sexual) people 3 . Both terms have strong cultural roots and political meanings outside the scope of this study 4 . Travesti is a Latin American gender identity generally understood as a person who performs roles socially perceived as feminine without necessarily changing their primary sexual characteristics 5 .

Bearing in mind the well-known health disparities that transgender populations endure - such as HIV infection prevalence and difficulties to access HIV-related care - 4,5,6 focused public health strategies are essential ${ }^{6}$. In many HIV studies, transgender women were included along with men who have sex with men, as it was stipulated that the route for infection was the same - unprotected anal sex 7 . Even today, the same mistake still occurs in compulsory notification for HIV in Brazil, making it impossible to analyze the two groups separately 8 . This misinterpretation of gender identity and sexual orientation in the scientific literature could be partially related to the outdated theory of sexual inversion, or psychological androgyny, which considers that gay men would be sexual inverts, with a "female soul", and that transgender women would simply be a hyper-feminized version of male homosexuality 9 . Today, it is clear that sexual orientation and gender identity are distinct domains 10 .

Named as a hidden population, the transgender populations are difficult to access, therefore studies that include them tend to adopt characteristic sampling methodologies, such as respondentdriven sampling (RDS), facility-based sampling (FBS), and time-location sampling (space - TLS) 7 . RDS is a network-based sampling method developed to enable access to hidden populations 11. It is a type of chain referral (or snowballing) method in which seeds, also called initial respondents, recruit peers 11. In each new RDS wave, recruits become recruiters and invite a pre-established number of peers 11, whereas both FBS and TLS refer to the place where the invitation occurs. In FBS, participants are invited from a variety of facilities that they usually attend, such as health services specialized in gender-affirming processes ${ }^{12}$. In TLS, the recruitment happens at locations where and when the target population may be found ${ }^{12}$. Studies also tend to use samples collected via the internet in groups where this audience is present or using the internet in conjunction with previous methodologies, such as RDS or FBS.

Based on the different approaches used to identify transgender populations, three methods are frequently used. The single-item measure consists of directly asking about the participants' gender identity. Traditionally, demographic surveys use this method and limit the participants' options to "male", "female", and, rarely, "transgender" 13. Although very simple, this single-item measure has some significant limitations 14 . The single-item measure can mislead information, because a transgender person may only identify as a male or a female. Besides, it does not consider the wide variety of non-binary genders. It also ignores culturally specific gender identities, that is, several segments of the transgender population as well as particularities that could improve the decision-making process in public health will remain invisible. A report of the William's Institute (United States) emphasized that the single-item measure combines gender assigned at birth and transgender identities in a way that limits identification to half the number of participants of other measures 15 . Furthermore, since it is not uncommon for transgender participants to self-identify as simply a woman or a man, misguiding the quality of data collected on cisgender populations as well 16,17,18.

The two-step measure, developed by a U.S. transgender community-based organization 18 , can overcome some of these challenges. The first question refers to the participants' gender assigned or registered at birth (male or female), whereas the second question inquires about their current gender identity (male, female, transgender men, transgender women, and other gender variations depending on the cultural context).

The main advantage of the two-question method is recognizing a wider spectrum of transgender and gender-diverse identities, including transgender people who prefer not to identify as such (for example, a woman whose gender assigned at birth was male), as well as other culturally-specific identi- 
ties 19. Also, the two-step measure allows participants who are sometimes unaware of gender-specific vocabulary, to disclose their gender identity using terminology that researchers will understand 14,20. For example, a North-American study conducted interviews with 25 cisgender and 25 transgender people aiming to identify measures that effectively recognize transgender status 20 . Both cisgender and transgender participants had difficulties understanding measures based exclusively on gender, whereas the "gender assigned at birth" was considered a clear and straightforward item. Indeed, four transgender participants chose male- or female-only options to describe their gender identities. Furthermore, a mixed-method study interviewed 36 cis- and transgender participants about the two-step measure 14 , and none reported difficulties in understanding the questions. When applied to a more substantial sample $(n>36,000)$ encompassing men from Spanish and Portuguese-speaking countries, the two-step measure was able to identify the expected prevalence of transgender people ${ }^{19}$. Therefore, the two-step measure effectively recognizes transgender and gender diverse populations, and it is currently considered to be the gold-standard for health surveillance 21 .

Finally, the third approach, widely used in FBS and TLS strategies, is the assumption that, for occupying transgender venues, one necessarily identifies themselves as transgender: a method we named "trans-assumption". We also considered "trans-assumption" in which the participants who did not receive instructions on defining gender identity, sexual orientation, or transgender women with peer-identification, frequently applied in RDS.

We aim to present the two-step measure as the best strategy for assessing gender diversity in Brazilian studies. Thus, we performed two separate analyses. Firstly, bearing in mind that most Brazilian publications including transgender people focus on HIV-related care 22, we conducted a systematic review concerning HIV-related care among Brazilian transgender and gender diverse populations to assess the strategy sued to identify participants' gender identity. Then, we re-analyzed data from a recent survey that included Brazilian transgender populations, comparing the characteristics and health outcomes from the samples identified by single-item and by the two-step measure providing data on the accuracy of this method.

\section{Methods}

\section{Systematic review}

To assess strategies used to identify transgender populations, Brazilian studies were re-analyzed concerning HIV-related care among transgender and gender diverse populations, found by a systematic review recently published by our group 7. Peer-reviewed quantitative studies, published up to April 4th, 2018, concerning transgender women, transgender men, and gender diverse people and HIVrelated care were included 7 . HIV-related care was considered as all interventions aiming to prevent, to treat, or to alleviate the impact of HIV on these populations. The review was registered online on the International Prospective Register of Systematic Reviews (PROSPERO 2017 CRD42017071213). For details regarding the methodology, see Fontanari et al. 7. As the two-question method was proposed around 2011, all included articles were published after 2015.

Information about recruitment and methodology used to assess gender identity was collected from the studies. Sample strategies were RDS, FBS, TLS, and internet-based survey (Internet). The measures for assessing gender identity were classified as unclear, single-item, two-step, or transassumption, based on what was explicitly mentioned in the article.

\section{Quantitative analysis}

To assess the impact of using different methods to recognize transgender people, data were re-analyzed from the Trans Health Research Project - the database utilized by Costa et al. 16. The Trans Health Research Project, a hospital- and web-based cross-sectional survey, was applied in two Brazilian states, Rio Grande do Sul and São Paulo. Transgender people seeking medical gender affirmation procedures from the two gender identity programs were invited by the researchers by convenience sampling to voluntarily answer the survey. Besides, the survey was available on the Internet during two time peri- 
ods: July-October 2014, and January-March 2015. The methods are described in detail in Costa et al. 16,23 and other studies derived from this research.

According to Costa et al. 16, gender identity was assessed using the two-step measure. Gender identity was questioned both by a closed-ended and a write-in. The closed-ended question was "which of the alternatives below best describes your current gender identity?", and the participant could choose between the options "female", "male", "transgender woman", "transgender man", "travesti", and "other". The alternative "other" offered participants an open-ended write-in, where several participants identified as gender-diverse persons. Participants were asked to disclose their gender assigned at birth by the question "What gender were you assigned at birth, on your original birth certificate?" using the alternatives "male" and "female". Based on the incongruence between their self-reported gender identity and their gender assigned at birth, participants were re-categorized as transgender women, transgender men, or gender diverse persons. That is, participants were categorized as "transgender women" when they selected both "male" to describe their sex assigned at birth and "female" or "transgender women" to characterize their gender identity; as "transgender men" when they checked "female" as their gender assigned at birth and "male" or "transgender men" as their gender identity; and as "gender diverse people" when they chose "female" or "male" as their gender assigned at birth, "others" as gender identity, and, after, described their gender identity (neutral, nonbinary, agender, pangender, genderqueer, two-spirit, third gender) in the write-in space.

To assess the impact of applying different methods to evaluate gender identity, sociodemographic characteristics were described using a sample of transgender people identified both by the single-item measure and by the two-step measure, as well as by a method we named "trans-assumption" - meaning that, if recruited on LGBT venues, participants would necessarily be transgender people.

Data management and statistical analyses were performed using SPSS software version 18.0 (https://www.ibm.com/). Frequencies were estimated according to sociodemographic characteristics. Both test sensitivity and specificity were calculated for the single-item measure considering the two-step measure as standard.

\section{Results}

\section{Systematic review}

From 6,585 references, 62 articles contained both HIV-related care and transgender people. Among them, Brazilian research teams published seven articles. As described in Box 1, most studies assumed that recruiting a sample from social organizations aiming to provide help to transgender populations, such as lesbian, gay, bisexual, transgender non-governmental organizations (LGBT NGO), would be enough to assure that participants were transgender people - an approach that, as peer-identification, we named as "trans-assumption". For example, Hoagland et al. 24,25 invited participants seeking HIV testing at an LGBT NGO and a mobile testing unit located in an LGBT-friendly venue. We applied one question concerning gender identity, and the participants were dichotomized into "male" and "transgender women". Castro et al. 26 used a similar strategy, inviting participants in front of an LGBT venue and at the site of Arco-Íris Group, a well-known LGBT NGO; however, we did not describe the method used to identity transgender populations.

Furthermore, studies that recruited samples through RDS counted on peer identification to guarantee that the participants were transgender women 27,28 . Therefore, Jalil et al. 27 (p. 2) indicated that "to participate, individuals had to self-identify as transgender women", and Pinheiro Júnior et al. 28 (p. 2) suggested that "each seed and study participant received three coupons to distribute to transgender women they knew by name and had seen in the past 30 days". Grinsztejn et al. 29 did not provide any data on how they identified their sample's gender identity. Notably, the participants did not receive directions on the concept of gender identity, sexual orientation, or transgender women. 
Box 1

Transgender HIV-related health study per sampling strategy and method to recognize gender identity.

\begin{tabular}{|c|c|c|c|c|}
\hline STUDY (YEAR) & MAIN OBJECTIVE & QUOTE & $\begin{array}{l}\text { SAMPLING } \\
\text { STRATEGY }\end{array}$ & $\begin{array}{l}\text { METHOD TO RECOGNIZE } \\
\text { GENDER IDENTITY }\end{array}$ \\
\hline Castro et al. 26 (2016) & $\begin{array}{l}\text { To assess the HIV-care } \\
\text { cascade among MSM and } \\
\text { TW newly diagnosed with } \\
\text { HIV infection. }\end{array}$ & $\begin{array}{l}\text { "Data collected at HIV testing } \\
\text { sites included: data and venue } \\
\text { of the test; date of birth; age; } \\
\text { city of residence; gender; sex } \\
\text { orientation..." (p. 3). }\end{array}$ & TLS & Unclear \\
\hline Costa et al. 16 (2018) & $\begin{array}{l}\text { To report HIV-related } \\
\text { healthcare needs and } \\
\text { access barriers among } \\
\text { transgender people. }\end{array}$ & $\begin{array}{l}\text { "Gender identity was } \\
\text { evaluated using the two- } \\
\text { question method, and subjects } \\
\text { were considered eligible to } \\
\text { participate if they reported } \\
\text { a gender different from that } \\
\text { assigned to them at birth" } \\
\text { (p. 2536). }\end{array}$ & FBS and internet & Two-step measure \\
\hline Grinsztejn et al. 29 (2018) & $\begin{array}{c}\text { PrEP retention, } \\
\text { engagement, and } \\
\text { adherence, trends in sexual } \\
\text { behavior, and incidence of } \\
\text { HIV and STIs among MSM } \\
\text { and TW. }\end{array}$ & $\begin{array}{l}\text { There were no mentions } \\
\text { of questions concerning } \\
\text { gender identity. }\end{array}$ & TLS and FBS & Unclear \\
\hline Hoagland et al. 24 (2017) & $\begin{array}{c}\text { PrEP awareness and } \\
\text { willingness among MSM } \\
\text { and TW. }\end{array}$ & $\begin{array}{l}\text { "Gender was self-reported and } \\
\text { dichotomized to Male and } \\
\text { Trans women" } \\
\text { (p. 1279). }\end{array}$ & TLS and FBS & Single-item measure \\
\hline Hoagland et al. 25 (2017) & $\begin{array}{c}\text { PrEP uptake and early } \\
\text { adherence among MSM } \\
\text { and TW. }\end{array}$ & $\begin{array}{c}\text { "Gender was considered as } \\
\text { Male or Transgender women" } \\
\text { (p. 3). }\end{array}$ & TLS and FBS & Single-item measure \\
\hline Jalil et al. 27 (2017) & $\begin{array}{c}\text { To estimate population- } \\
\text { level indicators of the HIV } \\
\text { cascade of care continuum } \\
\text { among TW. }\end{array}$ & $\begin{array}{l}\text { "To participate, individuals } \\
\text { had to self-identify as a } \\
\text { Transgender woman" (p. 2). }\end{array}$ & RDS & Peer-identification \\
\hline $\begin{array}{l}\text { Pinheiro Júnior et al. } 28 \\
\text { (2015) }\end{array}$ & $\begin{array}{l}\text { To identify risk factors } \\
\text { associated with resistance } \\
\text { to HIV testing among TW. }\end{array}$ & $\begin{array}{c}\text { "The sample was selected from } \\
\text { a list of members maintained } \\
\text { by the only transwoman } \\
\text { focused NGO..." (p. 1). } \\
\text { "Each seed and study } \\
\text { participant received three } \\
\text { coupons to distribute to } \\
\text { Transgender Woman they } \\
\text { know by name and have seen } \\
\text { in the past } 30 \text { days" (p. 2). }\end{array}$ & RDS & Peer-identification \\
\hline
\end{tabular}

FBS: facility-based sampling; GDP: gender-diverse people; MSM: men who have sex with men; PLHIV: people living with HIV; PrEP: pre-exposure prophylaxis; RDS: respondent-driven sampling; TLS: time-location sampling (space); TM: transgender men; TW: transgender women; TWSW: transgender women sex workers; TWLWH: transgender women living with HIV. 
Quantitative analysis

\section{- Different measures selected different samples}

Table 1 shows that trans-assumption would mean assuming that all the included participants identify as transgender or gender-diverse people. Among them, the single-item measure was able to recognize 540 transgender and gender diverse people - more precisely, 93 (17.2\%) travestis, 172 (31.9\%) transgender women, 156 (28.9\%) transgender men, and 119 (22\%) persons self-identified as "other" -, whereas the two-step measure identified 773 transgender and gender diverse people - 93 (12\%) travestis, 365 (47.2\%) transgender women, 196 (25.4\%) transgender men, and 119 (15.4\%) gender diverse people. The two-step measure also recognized 567 (42.3\%) cisgender participants among the 1,340 participants who started the survey. Furthermore, the sample selected by the three different approaches exhibited distinct characteristics.

Table 2 shows 31 (8.5\%) transgender women self-identified as "transgender men"; this suggests that, for them, the concept of transgender women differs from the one used in our manuscript. Furthermore, $162(44.4 \%)$ transgender women self-identified as women - meaning that the singleitem measure would not be able to recognize them. Out of the 196 transgender men, 71 (36.2\%) selfidentified as men-only and were not embraced by the single-item measure.

\section{Table 1}

Sociodemographic and HIV-related data concerning all participants, disregarding their gender identity, as well as participants' gender identity identified by the single-item and the two-step measures.

\begin{tabular}{|c|c|c|c|c|c|c|}
\hline \multirow[t]{2}{*}{ Sociodemographic } & \multicolumn{2}{|c|}{$\begin{array}{c}\text { All } \\
\text { participants }\end{array}$} & \multicolumn{2}{|c|}{$\begin{array}{l}\text { Single-item } \\
\text { measure }\end{array}$} & \multicolumn{2}{|c|}{$\begin{array}{l}\text { Two-step } \\
\text { measure }\end{array}$} \\
\hline & $\mathbf{N}$ & $\%$ & $\mathbf{n}$ & $\%$ & $\mathbf{n}$ & $\%$ \\
\hline Total & 1,340 & & 540 & & 773 & \\
\hline \multicolumn{7}{|l|}{ Age (years) } \\
\hline$\geq 45$ & 77 & 5.7 & 30 & 5.6 & 40 & 5.2 \\
\hline $35-44$ & 132 & 9.9 & 74 & 13.7 & 95 & 12.3 \\
\hline $25-34$ & 354 & 26.4 & 140 & 25.9 & 221 & 28.6 \\
\hline$\leq 24$ & 777 & 58.0 & 296 & 54.8 & 417 & 53.9 \\
\hline \multicolumn{7}{|l|}{ Ethnicity } \\
\hline White & 943 & 70.4 & 369 & 68.3 & 543 & 70.2 \\
\hline Non-white & 397 & 29.6 & 171 & 31.7 & 230 & 29.8 \\
\hline \multicolumn{7}{|l|}{ Education } \\
\hline Elementary school or less & 120 & 9.0 & 61 & 11.3 & 87 & 11.3 \\
\hline High school & 806 & 60.1 & 343 & 63.5 & 491 & 63.5 \\
\hline Undergraduate & 321 & 24.0 & 111 & 20.6 & 155 & 20.1 \\
\hline Graduate & 93 & 6.9 & 25 & 4.6 & 40 & 5.2 \\
\hline \multicolumn{7}{|l|}{ Brazilian state } \\
\hline São Paulo & 890 & 66.4 & 368 & 68.1 & 523 & 67.7 \\
\hline Rio Grande do Sul & 450 & 33.6 & 172 & 31.9 & 250 & 32.3 \\
\hline \multicolumn{7}{|l|}{ Relationship } \\
\hline Single & 629 & 46.9 & 255 & 47.2 & 380 & 49.2 \\
\hline Monogamous relationship & 576 & 43.0 & 217 & 40.2 & 310 & 40.1 \\
\hline Polygamous or open relationship & 135 & 10.1 & 68 & 12.6 & 83 & 10.7 \\
\hline \multicolumn{7}{|c|}{ Self-reported psychiatric diagnosis (lifetime) } \\
\hline Yes & 150 & 11.2 & 108 & 20.0 & 149 & 19.3 \\
\hline No & 1,190 & 88.8 & 432 & 80.0 & 624 & 80.7 \\
\hline
\end{tabular}

Note: in the first row, frequencies were calculated including all participants. In the second and third rows, frequencies were calculated encompassing participants recognized by the single-item and the two-step measures. 
Table 2

Misclassifications of gender identity based on the single-item versus the two-step measure.

\begin{tabular}{|c|c|c|c|c|c|c|c|}
\hline \multirow[t]{2}{*}{ Single-item measure } & \multirow[t]{2}{*}{ Travesti } & \multicolumn{6}{|c|}{ Two-step measure } \\
\hline & & $\begin{array}{c}\text { Gender-diverse } \\
\text { person }\end{array}$ & $\begin{array}{c}\text { Transgender } \\
\text { women }\end{array}$ & $\begin{array}{c}\text { Cisgender } \\
\text { women }\end{array}$ & $\begin{array}{c}\text { Transgender } \\
\text { men }\end{array}$ & $\begin{array}{l}\text { Cisgender } \\
\text { men }\end{array}$ & Total \\
\hline Travesti & 93 & 0 & 0 & 0 & 0 & 0 & 93 \\
\hline Other & 0 & 119 & 0 & 0 & 0 & 0 & 119 \\
\hline Transgender women & 0 & 0 & 172 & 0 & 0 & 0 & 172 \\
\hline Women & 0 & 0 & 162 & 308 & 0 & 0 & 470 \\
\hline Transgender men & 0 & 0 & 31 & 0 & 125 & 0 & 156 \\
\hline Men & 0 & 0 & 0 & 0 & 71 & 259 & 330 \\
\hline Total & 93 & 119 & 365 & 308 & 196 & 259 & 1,340 \\
\hline
\end{tabular}

\section{- Measure properties}

Considering the two-step measure as gold-standard, the single-item measure has a sensibility of 69.86\% (95\% confidence interval - 95\%CI: 66.49-73.08), a specificity of 100\% (95\%CI: 99.35-100.00), and accuracy of $82.61 \%$ (95\%CI: 80.47-84.61) for recognizing transgender and gender-diverse people. Thus, the single-item measure can correctly identify $69.86 \%$ of transgender and gender diverse people, all individuals who do not identify as transgender and gender diverse people, resulting in a precision of $82.61 \%$.

Notably, sensibility, specificity, and accuracy refer to correctly identifying transgender and gender-diverse people. Recognizing transgender and gender-diverse people, however, does not necessarily means identifying correctly transgender men and women. For example, 31 (8.5\%) transgender women were misclassified as "transgender men" by the single-item measure.

\section{Discussion}

Re-analyzing studies from the last 10 years, we concluded that just one applied the two-step measure. Furthermore, the data reanalysis showed that the different methods used to assess gender identity selected distinct samples. The two-step measure recognized 567 cisgender and 773 transgender and gender diverse participants among the 1,340 participants who started the questionnaire, whereas the single-item measure was able to recognize only 540 transgender and gender-diverse people. Moreover, 31 transgender women self-identified as "transgender men" on the single-item measure. Therefore, although scarcely used in Brazil, the two-step measure is a more accurate strategy to recognize gender identity.

In the reviewed studies, the most used method to assess gender identity was peer-identification, or "trans-assumption", in the context of RDS and TLS, that is, researchers went to places where transgender people usually gather (mainly NGOs) and asked them to self-identify (single-item measure) and/or to refer their peers. Observing the re-analysis of our survey, we found a problem in doing this as many LGB people can identify themselves as being in the transgender spectrum, as well as transgender persons could choose not to reveal their transgender identity or identify as gay or lesbian. As gender identity and sexual orientation are independent, transgender and gender-diverse people may also identify as LGB by attending LGB venues, and joining LGB surveys. The overlap between sexual orientation and gender identity is particularly true in Brazil since gender identity, expression, and sexual orientation are often viewed interchangeably by segments of the LGBT community, as well as the general society. For example, stereotypes of male homosexuality are frequently associated with feminine gender expression, as well as some travestis who could also self-identify as gay men 5,30. 
The aforementioned issue is particularly concerning in the context of TLS sampling. For example, the NGOs used in one of the TLS samplings were, in fact, LGBT NGOs - not just "T" 26. Therefore, online surveys directed to sexual and gender minorities may also include gay, lesbian, and bisexual people 31 . Applying the RDS method does not exactly overcome this issue, since the concept, as well as strategies to recognize, transgender may vary according to the recruiter and the seeds. Seed quality and subsequent assessment of gender identity are crucial in the RDS method. Without being sure of the participants' gender identity - which is only feasible with the two-step measure - even this more robust methodology may reinforce biases in the sample composition that would need to be considered. From our review, we concluded that the sampling technique is considered enough to identify transgender people; however, data analysis showed the opposite. Because the recruitment occurred on websites geared towards LGBT communities, LGB populations completed our survey. The twostep measure made it possible to identify these participants.

One study mixed sexual orientation and gender identity by asking only one question as a criterion for the inclusion of participants 29 . The overlap between sexual orientation and gender identity is criticized since it is assumed that all transgender women have sex with men, making different segments of the community invisible, for example, lesbian and bisexual transgender women who are at lower risk for infection, and transgender men 32,33. Besides, questions related to sexuality were not included in the studies that we reviewed, and it is not possible to know if the samples contain bisexual and homosexual transgender women or men, groups with different degrees of vulnerability for HIV infection. As exposed before, overcoming theories that consider sexual orientation and gender identity at the scientific level, and reaching autonomy of the transgender advocacy from the political movement around sexuality, also reinforced the position that it is fundamental to treat sexuality and gender as distinct domains 34 .

We conclude this paper with a proposal to be used in future studies in Brazil (Figure 1). The first question, as usual, asks about the gender on the civil registration ("a - female" or "b - male", according to the current Brazilian standards). Security is one of the main priorities among the best practices for the collection of data about gender minorities in South America 21. Considering the high systemic violence against transgender and gender-diverse populations, it is important to have an option to allow the passability as cisgender, not identifying the transgender status to the interviewer in moments where this identification may be risky to the participant's integrity. Therefore, we added "c" as an "I prefer not to answer" response option in the first question. For the second question, we kept "a woman" and "b - man" as the first response options. As stated before, this allows cisgender people to easily choose, for example, "male" in the first question and "man" in the second (or vice versa). At the same time, those two responses allow a transgender person who does not emphasize they "transgender" status to check, for example, "male" in the first option and "woman" in the second. This also allows those who answered "c", "prefer not to answer" in the first question to choose a gender identity that does not allow the identification as transgender.

In the third (c) and fourth (d) alternatives of the second question, we combine different ways in which the Brazilian population identifies itself around the Anglo-Saxon umbrella-term transgender (trans, transgender, transexual). Although we know that there is no consensus regarding these gender identities and that they can encompass different groups within the community, we have chosen to unite them as they denote the group of transgender people who prefer to make their identity visible as such 4 . Besides, following an international guideline 10, we have suggested making Brazilian-specific gender identities independent. For that, we included travestis as a fifth answer (e) in the second question. In our survey, many people who selected the "other" option later self-identified outside the gender binary. Research in other countries has shown an increase in this category in population surveys, thus we chose to make it an autonomous category ${ }^{35}$. Thus, "f" is an alternative for people who identify outside the gender binaries, such as gender fluid, agender or queer people. Finally, understanding the mutability of the forms of identification and gender itself, anyone who does not identify with the possibilities listed could opt for the last alternative, "other", and declare their specific gender identity "g".

All quantitative data collection implies choices. The method suggested here should not impose academic-oriented identities, but rather identify a broad spectrum of the community flexibly and comprehensively. Therefore, all questions could be edited by the researchers to add different alternatives to cover as broadly as possible how a given community identifies itself at the moment of the 
Figure 1

Brazilian proposal for the two-step measure of gender identity Portuguese and English versions.

1a) Portuguese version

\begin{tabular}{|c|c|}
\hline $\begin{array}{l}\text { 1) Como você foi designado(a) ao nascimento, nos seus } \\
\text { registros civis? }\end{array}$ & $\begin{array}{l}\text { 2) Quais das seguintes alternativas descreve melhor a forma como você } \\
\text { se identifica hoje? }\end{array}$ \\
\hline a) Feminino & a) Mulher \\
\hline b) Masculino & b) Homem \\
\hline \multirow[t]{5}{*}{ c) Prefiro não responder } & c) Mulher trans, mulher transexual ou mulher transgênero \\
\hline & d) Homem trans, homem transexual ou homem transgênero \\
\hline & e) Travesti \\
\hline & f) Queer, não-binário ou gênero fluído \\
\hline & g) Outro, qual? \\
\hline
\end{tabular}

1b) English version

\begin{tabular}{|ll}
\hline $\begin{array}{ll}\text { 1) What gender were you assigned at birth, on your original } \\
\text { birth certificate? }\end{array}$ & $\begin{array}{l}\text { 2) Which of the alternatives below best } \\
\text { gender identity? }\end{array}$ \\
\hline a) Female & a) Woman \\
b) Male & b) Man \\
c) Prefer not to answer & c) Transgender woman \\
& d) Transgender man \\
& e) Travesti \\
& f) Queer, non-binary or gender diverse \\
\hline
\end{tabular}

research implementation - for example, a third gender in the civil registration and/or culturallyspecific gender identities. Besides, in the spirit of community-based research, we recommend that members of the local transgender community - where the research will be applied - review these questions 36,37 . As aforementioned, this is a minimal proposal for data collection. However, for research focused on transgender and gender-diverse populations, it may be necessary to ask other complementary questions, such as medical and social procedures for gender affirmation, current or more frequent self-perceived public gender expressions, and the gender identity experienced most frequently (for gender-fluid people). In the context of transgender HIV-related research, we also suggested a question about sexual orientation 7 .

This study has one main limitation. We relied only on the information presented in the articles included in our systematic review. By contacting the authors, we could have detailed information on how gender identity was assessed. Thus, the category "trans-assumption" is itself an assumption that the included articles did not use a more sophisticated measure to assess gender identity. However, by unclearly describing the measure used to identify gender identity denotes how the procedure was secondary. Furthermore, it should be noted that, more recently, Brazilian studies adopted the twostep measure, such as Bastos et al. 38.

In conclusion, we ratify that the two-step measure is more accurate to identify transgender people and that almost all the articles recently published by Brazilian researchers on transgender HIV-related health are likely to present sampling bias. Unlike other countries, such as Canada and Uruguay, Brazil has not yet implemented a large-scale census-type strategy for documenting the living conditions of transgender and gender-diverse populations ${ }^{39}$. Debates on the 2020 census indicate that there is no 
intention to assess gender identity in the census research protocol 40 . The two-step question method should be adopted not just in the census, but in studies in the field of collective health dealing with this population, digital information system besides the surveillance notification forms from the Brazilian Unified National Health System (SUS).

\section{Contributors}

A. B. Costa, L. O. Rosa, and A. M. V. Fontanari drafted the manuscript and conceptualized the analysis. All authors approved the final version of the manuscript.

\section{Additional informations}

ORCID: Angelo Brandelli Costa (0000-0002-07428152); Letícia de Oliveira Rosa (0000-0002-45108918); Anna Martha Vaitses Fontanari (0000-00021457-3884).

\section{Acknowledgments}

We would like to acknowledgment the research participants whom, free of charge, took the time to answer a long questionnaire that, at times, explored sensitive aspects of their lives. Furthermore, we would like to thank the Brazilian research funding agencies, Brazilian National Research Council (CNPq), Brazilian Graduate Studies Coordinating Board (CAPES) and Rio Grande do Sul State Research Foudation (FAPERGS), as well as the universities Rio Grande do Sul Catholic University and Federal University of Rio Grande do Sul.

\section{References}

1. Drescher J, Cohen-Kettenis P, Winter S. Minding the body: situating gender identity diagnoses in the ICD-11. Int Rev Psychiatry 2012; 24:568-77.

2. Bockting WO. Transforming the paradigm of transgender health: a field in transition. Sex Relation Ther 2009; 24:103-7.

3. Carrara, S, Hernandez JDG, Uziel AP, Conceição GMS, Panjo H, Baldanzi ACO, et al. Body construction and health itineraries: a survey among travestis and trans people in Rio de Janeiro, Brazil. Cad Saúde Pública 2019; 35:e00110318.

4. Carvalho M, Carrara S. Em direito a um futuro trans?: contribuição para a história do movimento de travestis e transexuais no Brasil. Sex Salud Soc (Rio J.) 2013; (14):319-51.

5. Benedetti MR. Toda feita: o corpo e o gênero das travestis. Rio de Janeiro: Garamond; 2005.

6. Lo S, Horton R. Transgender health: an opportunity for global health equity. Lancet 2016; 388:316-8.

7. Fontanari AMV, Zanella GI, Feijó M, Churchill S, Lobato MIR, Costa AB. HIV-related care for transgender people: a systematic review of studies from around the world. Soc Sci Med 2019; 230:280-94.

8. Krüger A. Inserção dos campos "nome social” e "identidade de gênero" nos sistemas de vigilância em saúde: uma alternativa para qualificação da informação sobre a epidemia de HIV/aids na população trans brasileira [Monography]. Natal: Universidade Federal do Rio Grande do Norte; 2017. 
9. Drescher J. Queer diagnoses: parallels and contrasts in the history of homosexuality, gender variance, and the Diagnostic and Statistical Manual. Arch Sex Behav 2010; 39:427-60.

10. American Psychological Association. Guidelines for psychological practice with transgender and gender nonconforming people. Am Psychol 2015; 70:832-64.

11. Heckathorn DD. Respondent-driven sampling: a new approach to the study of hidden populations. Social Problems 1997; 44:174-99.

12. Shaghaghi A, Bhopal RS, Sheikh A. Approaches to recruiting 'hard-to-reach'populations into research: a review of the literature. Health Promot Perspect 2011; 1:86-94.

13. Greytak EA, Gill AM, Conron KJ, Herman JL. Best practices for asking questions to identify transgender and other gender minority respondents on population-based surveys. Los Angeles: Williams Institute; 2014.

14. Bauer GR, Braimoh J, Scheim AI, Dharma C. Transgender-inclusive measures of sex/gender for population surveys: mixed-methods evaluation and recommendations. PLoS One 2017; 12:e0178043.

15. Brown T, Herman J, Park A. Exploring international priorities and best practices for the collection of data about gender minorities, report of meeting. Los Angeles: Williams Institute; 2017.

16. Costa $\mathrm{AB}$, Fontanari AMV, Catelan RF, Schwarz K, Stucky JL, Rosa Filho HT, et al. HIV-related healthcare needs and access barriers for Brazilian transgender and gender diverse people. AIDS Behav 2018; 22:2534-42.

17. Fontanari AMV, Zanella GI, Feijó M, Churchill S, Lobato MIR, Costa AB. HIV-related care for transgender people: a systematic review of studies from around the world. Soc Sci Med 2019; 230:280-94.

18. Tate CC, Ledbetter JN, Youssef CP. A twoquestion method for assessing gender categories in the social and medical sciences. J Sex Res 2013; 50:767-76.

19. Reisner SL, Biello K, Rosenberger JG, Austin SB, Haneuse S, Perez-Brumer A, et al. Using a two-step method to measure transgender identity in Latin America/the Caribbean, Portugal, and Spain. Arch Sex Behav 2014; 43:1503-14.

20. Lombardi EL, Banik S. The utility of the twostep gender measure within trans and cis populations. Sex Res Social Policy 2016; 13:288-97.

21. Brown TNT, Herman J. Exploring international priorities and best practices for the collection of data about gender minorities: a focus on South America. Los Angeles: Williams Institute; 2020.

22. Cohen CR, De Tilio R. Revisão sistemática da literatura sobre atendimentos em saúde pública sob a perspectiva de pessoas transgêneros. Salud Soc 2019; 10:240-54.
23. Costa $A B$, da Rosa Filho HT, Pase PF, Fontanari AMV, Catelan RF, Mueller A, et al. Healthcare needs of and access barriers for Brazilian transgender and gender diverse people. J Immigr Minor Health 2018; 20:115-23.

24. Hoagland B, De Boni RB, Moreira RI, Madruga JVR, Kallas EG, Goulart SP, et al. Awareness and willingness to use pre-exposure prophylaxis (PrEP) among men who have sex with men and transgender women in brazil. AIDS Behav 2017; 21:1278-87.

25. Hoagland B, Moreira R, De Boni R, Kallas EG, Madruga JV, Vasconcelos R, et al. High preexposure prophylaxis uptake and early adherence among men who have sex with men and transgender women at risk for HIV infection: the PrEP Brasil demonstration project. J Int AIDS Soc 2017; 20:21472.

26. Castro R, Ribeiro-Alves M, Corrêa RG, Derrico $M$, Lemos $K$, Grangeiro JB, et al. The men who have sex with men HIV care cascade in Rio de Janeiro, Brazil. PLoS One 2016; 11:e0157309.

27. Jalil EM, Wilson EC, Luz PM, Velasque L, Moreira RI, Castro CV, et al. HIV testing and the care continuum among transgender women: population estimates from Rio de Janeiro, Brazil. J Int AIDS Soc 2017; 20:21873.

28. Pinheiro Júnior F, Kendall C, Martins T, Mota RMS, Macena RHM, Glick J, et al. Risk factors associated with resistance to HIV testing among transwomen in Brazil. AIDS Care 2016; 28:92-7.

29. Grinsztejn B, Hoagland B, Moreira RI, Kallas EG, Madruga JV, Goulart S, et al. Retention, engagement, and adherence to pre-exposure prophylaxis for men who have sex with men and transgender women in PrEP Brasil: 48 week results of a demonstration study. Lancet HIV 2018; 5:e136-45.

30. Green JN, Green JN. Beyond Carnival: male homosexuality in twentieth-century Brazil. Chicago: University of Chicago Press; 1999.

31. Gates GJ. LGBT demographics: comparisons among population-based surveys. Los Angeles: Williams Institute; 2014.

32. Bauer GR, Scheim AI. Sampling bias in transgender studies. Lancet Infect Dis 2013; 13:832.

33. Fontanari AM, Vianna LL, Schneider M, Soll BM, Schwarz K, Silva DC, et al. A retrospective review of medical records of laboratory-tested sexually transmitted infections of transsexual men from Southern Brazil. Arch Sex Behav 2019; 48:1573-9.

34. Connell R. Transsexual women and feminist thought: toward new understanding and new politics. Signs (Chic) 2012; 37:857-81.

35. Grant T. Statistics Canada begins testing nonbinary gender options in surveys. The Globe and Mail 2018; 13 may. https://www.theglo beandmail.com/canada/article-statistics-can ada-begins-testing-non-binary-gender-op tions-in-surveys/. 
36. Deutsch MB, Radix A, Reisner S. What's in a guideline? Developing collaborative and sound research designs that substantiate best practice recommendations for transgender health care. AMA J Ethics 2016; 18:1098-106.

37. Adams N, Pearce R, Veale J, Radix A, Castro D, Sarkar A, et al. Guidance and ethical considerations for undertaking transgender health research and institutional review boards adjudicating this research. Transgender Health 2017; 2:165-75.

38. Bastos FI, Bastos LS, Coutinho C, Toledo L, Mota JC, Velasco-de-Castro CA, et al. HIV, $\mathrm{HCV}, \mathrm{HBV}$, and syphilis among transgender women from Brazil: assessing different methods to adjust infection rates of a hard-to-reach, sparse population. Medicine (Baltimore) 2018; 97(1S Suppl 1):S16-24.
39. Ollin LC, Odman MG, Tangpricha AV. Worldwide prevalence of transgender and gender non-conformity. In: Ettner R, Monstrey S, Coleman E, editors. Principles of transgender medicine and surgery. New York: Routledge; 2016. p. 16-35.

40. Defensoria Pública da União. DPU recomenda ao IBGE que quantifique população trans no censo 2020. https://dpu.jusbrasil.com.br/ noticias/578047166/dpu-recomenda-ao-ib ge-que-quantifique-populacao-trans-no-cen so-2020 (accessed on 01/Jun/2020). 


\section{Resumo}

O reconhecimento correto da identidade de género em inquéritos populacionais é essencial para desenvolver estratégias eficazes de saúde pública para melhorar as duras condições de vida das populações transgênero e não binárias, além de coletar dados adequados sobre pessoas cisgênero. $O$ estudo tem como objetivo apresentar a medida de dois passos como a melhor estratégia para avaliar a identidade de gênero em inquéritos brasileiros. Para tanto, fizemos duas análises separadas. Primeiro, realizamos uma revisão sistemática sobre a assistência relacionada ao HIV em populações transgênero e não binárias brasileiras para avaliar a estratégia aplicada ao reconhecimento da identidade de gênero dos participantes. Depois, reanalisamos os dados de um inquérito recente que incluiu populações transgênero brasileiras, comparando as características e os desfechos de saúde na amostra identificada com as medidas de item único e de dois passos, respectivamente. Quanto à revisão sistemática, entre 6.585 referências, sete artigos foram publicados por pesquisadores brasileiros, e apenas um estudo aplicou a medida de dois passos. Com relação ao inquérito, a medida de dois passos reconheceu 567 pessoas cisgênero e 773 pessoas transgênero e não binárias entre os 1.340 participantes que iniciaram o questionário, enquanto a medida de item único reconheceu somente 540 pessoas transgênero e não binárias. Além disso, 31 mulheres transgênero se identificaram como "homens transgênero", quando foi usada a medida de item único. Portanto, embora a medida de dois passos seja pouco aplicada no Brasil, é uma estratégia mais precisa para reconhecer a identidade de gênero.

Identidade de Gênero; Inquéritos e Questionários; Revisão Sistemática; Viés de Seleção

\section{Resumen}

Reconocer correctamente la identidad de género en las encuestas basadas en población es esencial para desarrollar estrategias públicas de salud efectivas, con el objeto de mejorar las duras condiciones de vida de las poblaciones transgénero y de género diverso, así como recabar adecuadamente datos sobre personas cisgénero. El objetivo de este estudio es presentar un modelo de dos etapas como la mejor estrategia para evaluar la identidad de género en encuestas brasileñas. Para tal fin, se realizaron dos análisis separados. En primer lugar, se llevó a cabo una revisión sistemática relacionada con los cuidados recibidos por la población transgénero brasileña con VIH y poblaciones de género diverso, con el fin de evaluar la estrategia aplicada para reconocer la identidad de género de los participantes. En segundo lugar, volvimos a analizar los datos de una encuesta reciente, que incluyó a poblaciones transgénero brasileñas, comparando características y resultados de salud de la muestra identificada por un modelo de ítem único y por el modelo de dos etapas. Respecto a la revisión sistemática, de las 6.585 referencias se publicaron siete artículos por parte de equipos de investigación brasileños, $y$ solamente un estudio donde se aplicó el modelo de dos etapas. Respecto a esta encuesta, el modelo de dos etapas reconoció a 567 cisgénero y 773 transgénero, así como a participantes de género diverso, entre los 1.340 participantes que realizaron el cuestionario, aunque el modelo de un único ítem fue capaz de reconocer solo a 540 personas transgénero y de género diverso. Además, 31 mujeres transgénero se autoidentificaron como "hombres transgéneros" en el modelo de un único ítem. Por consiguiente, a pesar de que se aplicó escasamente en Brasil, el modelo de dos etapas es una estrategia más precisa para reconocer la identidad de género.

Identidad de Género; Encuestas y Questionarios; Revisión Sistemática; Sesgo de Selección
Submitted on 23/Jun/2020

Final version resubmitted on $22 / \mathrm{Jul} / 2021$

Approved on 29/Jul/2021 